\title{
Effects of future climate change on regional air pollution episodes in the United States
}

\section{Citation}

Mickley, L. J., D. J. Jacob, B. D. Field, and D. Rind. 2004. “Effects of Future Climate Change on Regional Air Pollution Episodes in the United States." Geophys. Res. Lett. 31 (24): L24103. doi:10.1029/2004gl021216.

\section{Published Version}

doi:10.1029/2004GL021216

\section{Permanent link}

http://nrs.harvard.edu/urn-3:HUL.InstRepos:14121816

\section{Terms of Use}

This article was downloaded from Harvard University's DASH repository, and is made available under the terms and conditions applicable to Other Posted Material, as set forth at http:// nrs.harvard.edu/urn-3:HUL.InstRepos:dash.current.terms-of-use\#LAA

\section{Share Your Story}

The Harvard community has made this article openly available.

Please share how this access benefits you. Submit a story.

\section{Accessibility}




\title{
Effects of future climate change on regional air pollution episodes in the United States
}

\author{
L. J. Mickley, D. J. Jacob, and B. D. Field \\ Division of Engineering and Applied Science, Harvard University, Cambridge, Massachusetts, USA \\ D. Rind \\ Goddard Institute for Space Studies, New York, New York, USA
}

Received 6 August 2004; revised 1 November 2004; accepted 22 November 2004; published 28 December 2004.

[1] We examine the impact of future climate change on regional air pollution meteorology in the United States by conducting a transient climate change (1950-2052) simulation in a general circulation model (GCM) of the Goddard Institute of Space Studies (GISS). We include in the GCM two tracers of anthropogenic pollution, combustion carbon monoxide $(\mathrm{COt})$ and black carbon $(\mathrm{BCt})$. Sources of both tracers and the loss frequency of COt are held constant in time, while wet deposition of $\mathrm{BCt}$ responds to the changing climate. Results show that the severity and duration of summertime regional pollution episodes in the midwestern and northeastern United States increase significantly relative to present. Pollutant concentrations during these episodes increase by $5-10 \%$ and the mean episode duration increases from 2 to 3-4 days. These increases appear to be driven by a decline in the frequency of mid-latitude cyclones tracking across southern Canada. The cold fronts associated with these cyclones are known to provide the main mechanism for ventilation of the midwestern and northeastern United States. Mid-latitude cyclone frequency is expected to decrease in a warmer climate; such a decrease is already apparent in long-term observations. Mixing depths over the midwest and northeast increase by $100-240 \mathrm{~m}$ in our future-climate simulation, not enough to compensate for the increased stagnation resulting from reduced cyclone frequency. INDEX TERMS: 0345 Atmospheric Composition and Structure: Pollution - urban and regional (0305); 0368 Atmospheric Composition and Structure: Troposphere-constituent transport and chemistry; 1610 Global Change: Atmosphere $(0315,0325)$. Citation: Mickley, L. J., D. J. Jacob, B. D. Field, and D. Rind (2004), Effects of future climate change on regional air pollution episodes in the United States, Geophys. Res. Lett., 31, L24103, doi:10.1029/2004GL021216.

\section{Introduction}

[2] Long-term projections for surface air quality in the United States must account not only for future changes in emissions but also for changes in climate. The frequency of pollution episodes varies considerably from year to year depending on weather [e.g., Vukovich, 1995; Lin et al., 2001], pointing to the potential importance of climate change. Several model studies have examined the sensitivity of ozone and aerosols to changes in temperature and humidity [Bufalini et al., 1989; Sillman and Samson, 1995; Aw and Kleeman, 2003]. More important may be the sensitivity to changes in mixing depths, frequency of stagnation episodes, and synoptic-scale circulations [e.g., Logan, 1989; Vukovich and Sherwell, 2002]. We explore these effects here with a general circulation model (GCM) transient simulation of 2000-2050 climate change.

[3] We focus on the eastern and midwestern United States where pollution episodes tend to extend over regional scales greater than 500,000 $\mathrm{km}^{2}$ [Logan, 1989; Eder et al., 1993], in contrast to the more mountainous west where they tend to be local and affected by topography [e.g., Pun and Seigneur, 1999; Winner and Cass, 1999]. Regional pollution episodes in the east and midwest are associated with slowly moving high pressure systems with restricted boundary layer ventilation [e.g., Schichtel and Husar, 2001; Hogrefe et al., 2004]. The episodes are terminated by mid-latitude cyclones traveling eastward across southern Canada [Dickerson et al., 1995; Merrill and Moody, 1996; Stohl, 2001]. The cold fronts associated with these cyclones sweep across the northern United States, lifting polluted air to the free troposphere in warm conveyor belts ahead of the front and replacing it with clean high-latitude air behind the front [Cooper et al., 2001]. The fronts generally do not reach into the southeastern United States, and ventilation there is mostly driven by deep convection and inflow from the Gulf of Mexico (Q. Li et al., Outflow pathways for North American pollution in summer: a global 3-D model analysis of MODIS and MOPITT observations, submitted to Journal of Geophysical Research, 2004, hereinafter referred to as $\mathrm{Li}$ et al., submitted manuscript, 2004).

[4] Only a few GCM studies have examined the effect of climate change on pollution transport, and then only in a very general sense. Rind et al. [2001] found that increased convection in a doubled- $\mathrm{CO}_{2}$ atmosphere led to improved ventilation of the continental boundary layer. Holzer and Boer [2001] found that weaker winds in a warmer climate led to higher concentrations in pollution plumes. We present here a more specific analysis of the effect of future climate change on the frequency and severity of pollution episodes in the United States. For this purpose, we use a GCM transient model simulation for 2000-2050 including two simple tracers of anthropogenic pollution, combustion carbon monoxide (CO) and black carbon aerosol (BC). Emissions for both tracers are held constant over the simulation, so that any trends in concentration are driven solely by climate change.

\section{Methods}

[5] We implemented the $\mathrm{CO}$ and $\mathrm{BC}$ tracers into the Goddard Institute for Space Studies (GISS) GCM 2' [Rind 
and Lerner, 1996; Rind et al., 1999]. The GCM version used here has a "qflux ocean" [Hansen et al., 1988] and a horizontal resolution of $4^{\circ}$ latitude and $5^{\circ}$ longitude, with nine vertical layers in a sigma coordinate system extending from the surface to $10 \mathrm{hPa}$. The three lowest layers are centered at about $260 \mathrm{~m}, 860 \mathrm{~m}$, and $1900 \mathrm{~m}$ for an air column based at sea level. In the qflux model, monthly mean ocean heat transport fluxes are first calculated to generate observed, present-day sea surface temperatures. In subsequent simulations, sea surface temperatures and ocean ice respond to changes in climate, while the ocean heat transport fluxes are held fixed.

[6] The $\mathrm{CO}$ and $\mathrm{BC}$ tracers are denoted here as "COt" and "BCt" to emphasize their generic nature. The source of $\mathrm{COt}$ in the model is present-day fossil fuel $\mathrm{CO}$ emissions [Wang et al., 1998], and COt loss is by reaction with $\mathrm{OH}$ as computed from present-day, monthly mean $\mathrm{OH}$ fields [Mickley et al., 2004]. We ignore any perturbations to $\mathrm{OH}$ due to climate change [Johnson et al., 1999; Shindell et al., 2001] in order to isolate the effect of transport. The BCt source is present-day global BC emissions from Park et al. [2003]. BCt is assumed to be scavenged efficiently by wet deposition, which in our model follows the scheme of Koch et al. [1999].

[7] The transient climate simulation was performed from 1950 to 2052 with concentrations of the well-mixed greenhouse gases $-\mathrm{CO}_{2}, \mathrm{CH}_{4}, \mathrm{~N}_{2} \mathrm{O}$, and halocarbons - updated yearly. For 1950-2000 we used observations [Hansen et al., 2002]. For 2000-2052 we used the A1B scenario from the Intergovernmental Panel on Climate Change (IPCC), with $\mathrm{CO}_{2}$ as implemented in the Bern-CC model [Houghton et al., 2001]. For future halocarbons we followed Hansen et al. [2002]. We fixed ozone and aerosol concentrations in the radiative scheme at present-day climatological values.

[8] Results for the years 1995-2052 were analyzed. The long spin-up time allows the calculated sea surface temperatures to adjust. From 1995 to 2052 we calculate a globally averaged surface temperature increase of $1.9^{\circ} \mathrm{C}$, corresponding to a forcing of $2.1 \mathrm{~W} \mathrm{~m}^{-2}$. Precipitation rates over the southeastern United States decrease by as much as $20 \%$ in summer, but increase by $20 \%$ in winter due to increased southerly transport of moist tropical air. Elsewhere in the United States, precipitation rates do not change significantly in the future scenario. Analysis of model results focuses on daily mean concentrations. Because the vertical resolution of the boundary layer is coarse, simulated surface air concentrations show little diurnal variation and are most representative of daytime conditions, when the mixed layer is deep [Jacob et al., 1993a].

\section{Results}

[9] For the present-day period 1995-2002, surface COt concentrations over the United States range from 50$150 \mathrm{ppb}$ in summer to $150-200 \mathrm{ppb}$ in winter. These are lower than observed $\mathrm{CO}$ concentrations since we have not included biomass burning or chemical production as sources of COt. A more complete tropospheric chemistry simulation conducted previously with the same GCM for present-day conditions showed a good representation of $\mathrm{CO}$ concentrations [Mickley et al., 1999]. For BCt in source regions of the United States, simulated mean concentrations in surface air range from about $0.6-1.1 \mu \mathrm{g} \mathrm{m}^{-3}$ in winter to $0.4-$
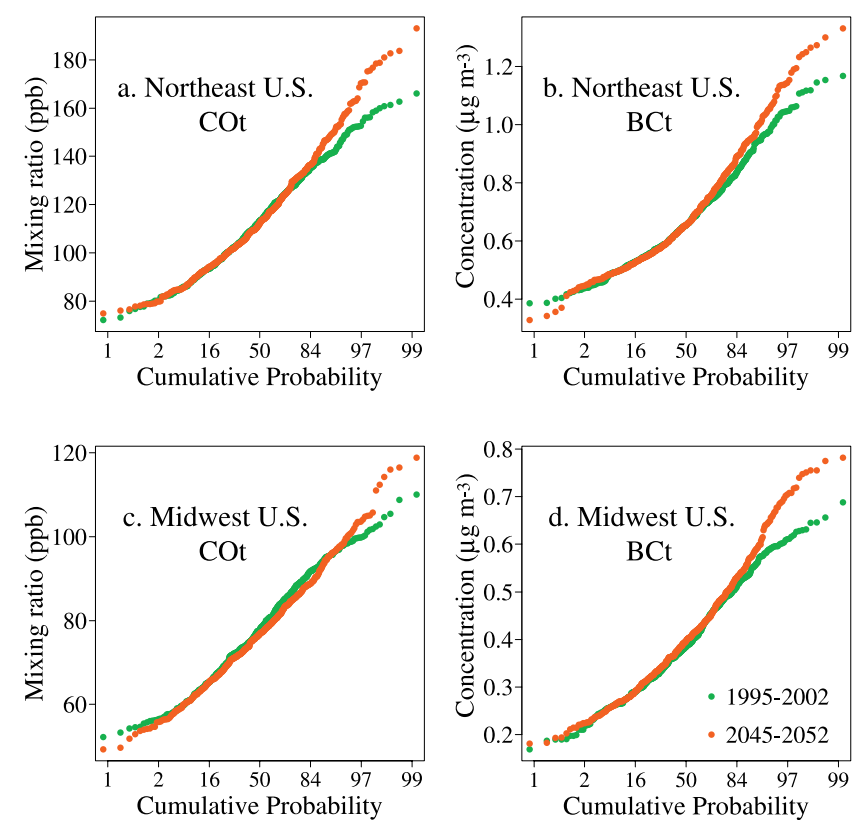

Figure 1. Cumulative frequency distributions of simulated daytime concentrations of combustion carbon monoxide (COt) and black carbon (BCt) averaged over the northeastern and midwestern United States in July and August. Each point represents the spatial average for a particular day. Results are shown for the present-day climate (19952002 , in green), and the future A1B climate (2045-2052, in red). To isolate the effect of climate change, sources of COt and $\mathrm{BCt}$ and the sink of $\mathrm{COt}$ are the same for the presentday and future simulations.

$0.7 \mu \mathrm{g} \mathrm{m}^{-3}$ in summer, roughly consistent with observations for BC [Park et al., 2003].

[10] We find that seasonal mean surface concentrations of COt and BCt for the years 2045-2052 show in general no significant change relative to present-day. Over the southeastern United States in winter, the increase in precipitation reduces seasonal mean $\mathrm{BCt}$ by $5 \%$. A better indicator of the response of air quality to a changing climate is the change in the intensity and duration of high pollution episodes. We examined the cumulative frequency distributions of daily mean surface concentrations of COt and $\mathrm{BCt}$ averaged over 6 regions of the United States: (1) the northeast, which includes New England, the mid-Atlantic states, Ohio, West Virginia, Virginia, and eastern Kentucky; (2) the southeast, which extends from eastern Texas to the Atlantic coast; (3) the midwest, which extends from eastern Colorado to Indiana and as far south as Missouri; (4) the southwest; (5) the northwest; and (6) California. The regions range in size from 16 gridboxes (the midwest) to 3 (California).

[11] The largest changes in the frequency distributions for surface $\mathrm{COt}$ and $\mathrm{BCt}$ concentrations occur over the northeast and midwest in summer, defined here as July-August. In Figure 1, we show the summertime distributions over these two regions for 2045-2052 and 1995-2002. Median and background concentrations do not change significantly. Concentrations at the high end of the distributions, representing pollution episodes, are greater by $5-10 \%$ in the future climate. The change is statistically significant $(p<$ 0.05 ) above the 84th percentile for $\mathrm{COt}$ and $\mathrm{BCt}$ in the 
northeast and for $\mathrm{BCt}$ in the midwest, representing a collection of 79 days for each 8 -year period. The change is also significant above the 97.5 th percentile for COt in the midwest (12 days for each 8-year period). Our results indicate an increase in the severity of summertime pollution episodes in these two regions by 2050 . Elsewhere in the United States in summer and for most regions during other seasons, we do not detect significant differences in the frequency distributions of concentrations between presentday and 2050 climates.

[12] Surface concentrations in the northeast in the model correlate highly with those of the midwest with a $1-2$ day time lag, consistent with observations [Logan, 1989; Moody et al., 1998]. The correlation implies that the same synopticscale transport mechanisms govern pollution episodes in both regions. Daily mean maximum mixing depths, which average $1.1 \mathrm{~km}$ (northeast) and $1.3 \mathrm{~km}$ (midwest) in the present-day, increase significantly in the future by $100-$ $240 \mathrm{~m}(\mathrm{p}<0.05)$, consistent with higher surface temperatures and greater vertical mixing [Rind et al., 2001]. The change in future mixing depths is of the wrong sign to explain the increase in severity of future pollution events.

[13] Time series of BCt and COt surface concentrations over the northeast and midwest in summer show greater autocorrelation in the future than for present-day. We counted the number of consecutive days with regional concentrations above the 84th percentile as representative of pollution episodes. Over the midwest we found an increase of episode duration from 2.3 days to 3.0 days for COt and from 2.4 days to 4.6 days for BCt. In the northeast, COt pollution episodes lengthen from 2 to 2.5 days, but the change for $\mathrm{BCt}$ episodes is negligible.

[14] Termination of pollution episodes in the midwest and northeast is driven by cyclones crossing southern Canada and the associated cold fronts, which sweep away pollution [Cooper et al., 2001]. To calculate trends in surface cyclone frequency in the model, we counted the number of times each summer when the mean sea level pressure over Quebec dropped for two consecutive days to below the mean for that summer and then rose on the third day. Using the same method, we also counted the number of surface cold air surges into the midwestern United States from Canada. We found that the average number of cyclones crossing Quebec decreased slightly in the future simulation relative to the present, from 7.5 cyclones per summer to 6.8 . The number of cold surges into the midwest decreased $20 \%$, from 6.2 events per summer to 5 . The uncertainty in these trends is large; to calculate statistically significant trends would require more years of daily model output. In observations, cold fronts ventilate the northeast every $4-5$ days in JulyAugust (Li et al., submitted manuscript, 2004), for a total of about 14 events during those two months. Our method underestimates the number of cyclones and cold surges, which may reflect our definition of these events or the coarse resolution of the model. However, as discussed below, decreasing cyclone frequency in the future climate appears to be a robust result.

\section{Discussion}

[15] Our results suggest that a warming climate could increase the severity of summertime pollution episodes in the northeastern and midwestern United States. The increase in severity appears to be caused by a decrease in the frequency of surface cyclones tracking across southern Canada. Our model trend in cyclone frequency is consistent with observed long-term trends over North America [Zishka and Smith, 1980] and more generally at northern midlatitudes [Agee, 1991; Key and Chan, 1999; McCabe et al., 2001]. For example, Zishka and Smith [1980] found an $8 \%$ decline per decade in the number of July surface cyclones over North America for the period 1950-1977.

[16] Previous GCM studies with increasing greenhouse gases have also calculated a decline in mid-latitude cyclone frequency. Probable causes for this trend include (1) a decrease in the extratropical meridional temperature gradient from the surface through the mid-troposphere, which reduces baroclinicity [Carnell and Senior, 1998; Geng and Sugi, 2003], and (2) an increase in the magnitude and efficiency of the meridional eddy transport of latent heat, which reduces the number of cyclones required to maintain the meridional temperature gradient [Zhang and Wang, 1997]. Consistent with these studies, we find that the meridional temperature gradient in the lower troposphere between $30 \mathrm{~N}$ and $55 \mathrm{~N}$ over eastern North America weakens in summer by about $1^{\circ} \mathrm{C}$. Over mid-latitudes at $600-$ $800 \mathrm{hPa}$, the northward, zonally averaged eddy transport of latent heat increases in summer by $5-10 \%$.

[17] We conclude that reduced cyclone frequency in a future warmer climate will lead to an increase in the severity of summertime pollution episodes in the northeastern and midwestern United States. Although the GCM used in our analysis is relatively coarse, the decrease in cyclone frequency and implication for air quality appears to be a robust result. It is well established that cyclones play a critical role in ventilating pollution from these regions. There is also compelling evidence that the frequency of these cyclones has been decreasing over the past decades. This decrease is likely to continue in the future due to increases in greenhouse gases. Quantitative analysis of the implications for future air quality will require regional climate models with detailed chemistry, but the computational demands of such models are formidable. Statistical analysis of observed correlations between pollutant concentrations and meteorological parameters may provide a useful tool to predict pollution trends in GCM simulations. For example, the observed correlation of ozone with temperature in the eastern United States is known to reflect the influences of chemistry, biogenic emissions, and stagnation [Jacob et al., 1993b]. GCM simulations of future temperature change could thus be used to predict future surface ozone changes.

[18] Acknowledgments. This work was funded by the U.S. Environmental Pollution Agency, IAG DW-4793948201 and STAR R830959 grants. It contributes to the Climate Impacts on Regional Air Quality project in the USEPA National Exposure Research Laboratory. We thank Dylan Jones for useful discussions.

\section{References}

Agee, E. M. (1991), Trends in cyclone and anticyclone frequency and comparison with periods of warming and cooling over the Northern Hemisphere, J. Clim., 4, 263-267.

Aw, J., and M. J. Kleeman (2003), Evaluating the first-order effect of intraannual temperature variability on urban air pollution, J. Geophys. Res., 108(D12), 4365, doi:10.1029/2002JD002688.

Bufalini, J. J., P. L. Finkelstein, and E. C. Durman (1989), Air quality, in The Potential Effects of Global Climate Change on the United States, pp. 195-213, Environ. Protect. Agency, Washington, D. C. 
Carnell, R. E., and C. A. Senior (1998), Changes in mid-latitude variability due to increasing greenhouse gases and sulfate aerosols, Clim. Dyn., 14, $369-383$

Cooper, O. R., et al. (2001), Trace gas signatures of the airstreams within North Atlantic cyclones: Case studies from the North Atlantic Regional Experiment (NARE '97) aircraft intensive, J. Geophys. Res., 106, $5437-$ 5456.

Dickerson, R. R., B. Doddridge, P. Kelley, and K. Rhoads (1995), Large scale pollution of the atmosphere over the remote Atlantic Ocean: Evidence from Bermuda, J. Geophys. Res., 100, 8945-8952.

Eder, B. K., J. M. Davis, and P. Bloomfield (1993), A characterization of the spatiotemporal variability of non-urban ozone concentrations over the eastern United States, Atmos. Environ., Part A, 27, 2645-2668.

Geng, Q., and M. Sugi (2003), Possible change of extratropical cyclone activity due to enhanced greenhouse gases and sulfate aerosols-Study with a high-resolution AGCM, J. Clim., 16, 2262-2274.

Hansen, J., I. Fung, A. Lacis, D. Rind, S. Lebedeff, R. Ruedy, and G. Russell (1988), Global climate changes as forecast by Goddard Institute for Space Studies three-dimensional model, J. Geophys. Res., 93, $9341-9364$

Hansen, J., et al. (2002), Climate forcings in Goddard Institute for Space Studies SI2000 simulations, J. Geophys. Res., 107(D18), 4347, doi:10.1029/2001JD001143.

Hogrefe, C., J. Biswas, B. Lynn, K. Civerolo, J.-Y. Ku, J. Rosenthal, C. Rosenzweig, R. Goldberg, and P. L. Kinney (2004), Simulating regional-scale ozone climatology over the eastern United States: Model evaluation results, Atmos. Enironv., 38, 2627-2638.

Holzer, M., and G. J. Boer (2001), Simulated changes in atmospheric transport climate, J. Clim., 14, 4398-4420.

Houghton, J. T., Y. Ding, D. J. Griggs, M. Noguer, P. J. van der Linden, X. Dai, K. Maskell, and C. A. Johnson (2001), Climate Change 2001 . The Scientific Basis, Contribution of Working Group I to the Third Assessment Report of the Intergovernmental Panel on Climate Change, 881 pp., Cambridge Univ. Press, New York.

Jacob, D. J., et al. (1993a), Simulation of summertime ozone over North America, J. Geophys. Res., 98, 14,797-14,816.

Jacob, D. J., J. A. Logan, G. M. Gardner, R. M. Yevich, C. M. Spivakovsky, S. C. Wofsy, S. Sillman, and M. J. Prather (1993b), Factors regulating ozone over the United States and its export to the global troposphere, J. Geophys. Res., 98, 14,817-14,826.

Johnson, C. E., W. J. Collins, D. S. Stevenson, and R. G. Derwent (1999), Relative roles of climate and emissions changes on future tropospheric oxidant concentrations, J. Geophys. Res., 104, 18,631-18,645.

Key, J. R., and A. C. K. Chan (1999), Multidecadal global and regional trends in $1000 \mathrm{mb}$ and $500 \mathrm{mb}$ cyclone frequencies, Geophys. Res. Lett. $26,2053-2056$

Koch, D., D. Jacob, I. Tegen, D. Rind, and M. Chin (1999), Tropospheric sulfur simulation and sulfate direct radiative forcing in the Goddard Institute for Space Studies general circulation model, J. Geophys. Res., 104, 23,799-23,822.

Lin, C.-Y. C., D. J. Jacob, and A. M. Fiore (2001), Trends in exceedances of the ozone air quality standard in the continental United States, 1980 1998, Atmos. Environ., 35, 3217-3228.

Logan, J. A. (1989), Ozone in rural areas of the United States, J. Geophys. Res., 94, 8511-8532.

McCabe, G. J., M. P. Clark, and M. C. Serreze (2001), Trends in Northern Hemisphere surface cyclone frequency and intensity, J. Clim., 14, $2763-$ 2768

Merrill, J. T., and J. L. Moody (1996), Synoptic meteorology and transport during the North Atlantic Regional Experiment (NARE) intensive: Overview, J. Geophys. Res., 101, 28,903-28,921.

Mickley, L. J., P. P. Murti, D. J. Jacob, J. A. Logan, D. Rind, and D. Koch (1999), Radiative forcing from tropospheric ozone calculated with a unified chemistry-climate model, J. Geophys. Res., 104, 30,153-30,172.
Mickley, L. J., D. J. Jacob, B. D. Field, and D. Rind (2004), Climate response to the increase in tropospheric ozone since preindustrial times: A comparison between ozone and equivalent $\mathrm{CO}_{2}$ forcings, J. Geophys. Res., 109, D05106, doi:10.1029/2003JD003653.

Moody, J. L., J. W. Munger, A. H. Goldstein, D. J. Jacob, and S. C. Wofsy (1998), Harvard Forest regional-scale air mass composition by Patterns in Atmospheric Transport History (PATH), J. Geophys. Res., 103, 13,18113,194.

Park, R. J., D. J. Jacob, M. Chin, and R. V. Martin (2003), Sources of carbonaceous aerosols over the United States and implications for natural visibility, J. Geophys. Res., 108(D12), 4355, doi:10.1029/ 2002JD003190.

Pun, B. K., and C. Seigneur (1999), Understanding particulate matter formation in the California San Joaquin Valley: Conceptual model and data needs, Atmos. Environ., 33, 4865-4875.

Rind, D., and J. Lerner (1996), Use of on-line tracers as a diagnostic tool in general circulation model development: 1 . Horizontal and vertical transport in the troposphere, J. Geophys. Res., 101, 12,667-12,683.

Rind, D., J. Lerner, K. Shah, and R. Suozzo (1999), Use of on-line tracers as a diagnostic tool in general circulation model development: 2 . Transport between the troposphere and the stratosphere, J. Geophys. Res., 104, 9123-9139.

Rind, D., J. Lerner, and C. McLinden (2001), Changes of tracer distribution in the doubled $\mathrm{CO}_{2}$ climate, J. Geophys. Res., 106, 28,061-28,080.

Schichtel, B. A., and R. B. Husar (2001), Eastern North American transport climatology during high- and low-ozone days, Atmos. Environ., 35, $1029-1038$.

Shindell, D. T., L. Grenfell, D. Rind, and V. Grewe (2001), Chemistryclimate interactions in the Goddard Institute for Space Studies general circulation model, J. Geophys. Res., 106, 8047-8075.

Sillman, S., and P. J. Samson (1995), Impact of temperature on oxidant photochemistry in urban, polluted rural, and remote environments, J. Geophys. Res., 100, 11,497-11,508.

Stohl, A. (2001), A 1-year Lagrangian "climatology" of airstreams in the Northern Hemisphere troposphere and lowermost stratosphere, J. Geophys., Res., 106, 7263-7279.

Vukovich, F. M. (1995), Regional-scale boundary-layer ozone variations in the eastern United States and their association with meteorological variations, Atmos. Environ., 29, 2259-2273.

Vukovich, F. M., and J. Sherwell (2002), Comparison of fine particles and the relationship between particle variation and meteorology at an urban site and a remote site in the eastern United States, J. Air Waste Manage. Assoc., 52, 573-584.

Wang, Y., D. J. Jacob, and J. A. Logan (1998), Global simulation of tropospheric $\mathrm{O}_{3}-\mathrm{NO}_{\mathrm{x}}$-hydrocarbon chemistry: 1. Model formulation, J. Geophys. Res., 103, 10,713-10,725.

Winner, D. A., and G. R. Cass (1999), Modeling the long-term frequency distribution of regional ozone concentrations, Atmos. Environ., 33, 431452

Zhang, Y., and W. C. Wang (1997), Model-simulated northern winter cyclone and anticyclone activity under a greenhouse warming scenario, J. Clim., 10, 1616-1634

Zishka, K. M., and P. J. Smith (1980), The climatology of cyclones and anticyclones over North America and surrounding ocean environs for January and July, 1950-1977, Mon. Weather Rev., 108, 387-401.

B. D. Field, D. J. Jacob, and L. J. Mickley, Division of Engineering and Applied Science, Harvard University, Cambridge, MA 02138, USA. (ljm@io.harvard.edu)

D. Rind, Goddard Institute for Space Studies, New York, NY 10025 , USA. 